A RCHIWA, BIBLIOTEKI

I MUZEA KOŚCIELNE 112 (2019)

https://doi.org.10.31743/abmk.2019.112.07

\title{
KSIĘGOZBIORY KOLEGIÓW KANONICKICH ARCHIDIAKONATU WOJNICKIEGO DO 1786 ROKU
}

\begin{abstract}
Streszczenie
Istniejące w granicach archidiakonatu wojnickiego dwie kolegiaty w Wojniczu i Bobowej posiadały swoje księgozbiory. Od strony zasobności były to biblioteki zbliżone, kolegiata w Wojniczu - 77 tytułów, w Bobowej - ok. 50. Trzon obydwu zasobów bibliotecznych stanowiły księgi z zakresu teologii, kaznodziejstwa, filozofii, prawa i historii. Rangę zbioru wojnickiego podnoszą zachowane do dziś cenne oprawy gotyckie i renesansowe na wielu XV-wiecznych księgach, nieco zniszczone przez upływ czasu. Obie biblioteki kolegiackie, choć powstały w różnym czasie i okolicznościach (Wojnicz - 1465, Bobowa 1529), gromadziły księgi tematycznie związane z pracą duszpasterską, co jest szczególnie widoczne w przypadku Bobowej. Z kolei w przypadku kolegiaty w Wojniczu wiele cennych dzieł należało do kanoników, którzy wcześniej gromadzili je na okoliczność odbywanych studiów i pracy na uniwersytecie, z czasem przekazując je w drodze legatu testamentowego do zbiorów biblioteki kolegiackiej. Bez wątpienia księgozbiór kolegiaty w Wojniczu należał do znaczących pod względem zawartości treściowej ksiąg, jak również czasu ich wydania, w Bobowej zaś miał zdecydowanie charakter pragmatyczny.

Słowa kluczowe: Wojnicz; Bobowa; księgozbiór; kolegiata; kanonicy
\end{abstract}

Ważnym elementem terytorialnej organizacji Kościoła od XIII wieku był archidiakonat. Urząd archidiakona w Kościele powszechnym znany był znacznie wcześniej. Zarówno na Wschodzie, jak i Zachodzie powstał i rozwijał się od IV do VII wieku' ${ }^{1}$. Pierwsza wzmianka o istnieniu archidiakonatu w Polsce pochodzi

* Ks. Waldemar Graczyk - prof. historii; Instytut Nauk Historycznych Uniwersytetu Kardynała Stefana Wyszyńskiego w Warszawie; e-mail: waldemar-graczyk@wp.pl

https://orcid.org/ 0000-0002-8057-8368

${ }^{1}$ B. Kumor, Archidiakonat, w: Encyklopedia katolicka (dalej: EK), t. 1, red. F. Gryglewicz, Lublin 1973, kol. 869. 
$\mathrm{z}$ archidiecezji gnieźnieńskiej. Przekazał ją w roku 1108 Anonim zwany Gallem² . Od końca XII wieku w przekazach źródłowych można znaleźć informację o istnieniu w Polsce archidiakonatu nowego typu, czyli archidiakonatu okręgowego ${ }^{3}$. Uprawnienia archidiakona od średniowiecza regulowały przepisy prawa kościelnego, np. Dekret Gracjana czy uchwały synodów polskiej prowincji kościelnej ${ }^{4}$. Do obowiązków archidiakona należało wizytowanie parafii oraz informowanie biskupa o nadużyciach duchowieństwa, troska o liturgię na powierzonym ich pieczy terytorium, a od 1530 roku (synod piotrkowski) nałożono na archidiakonów obowiązek czuwania nad czystością wiary katolickiej w kontekście rozprzestrzeniania się luteranizmus. Od drugiej połowy XII wieku obserwowano tendencję do podziału archidiakonatów na mniejsze jednostki organizacji terytorialnej, tzw. dekanaty. Zwyczaj ten upowszechnił się w XIII i XIV wieku, a zadecydowały o tym głównie względy administracyjne ${ }^{6}$.

Archidiakonat wojnicki powstał stosunkowo późno - w połowie XVIII wieku. Myśl o jego utworzeniu zrodziła się w kontekście wizytacji kolegiaty pw. św. Wawrzyńca, którą przeprowadził biskup krakowski Andrzej Stanisław Kostka Załuski (1746-1758) w listopadzie 1749 roku$^{7}$. Podnoszona kwestia rozległości terytorialnej archidiakonatu krakowskiego, do którego należało w połowie XVIII wieku 17 dekanatów oraz 372 parafie, oraz związane z tym i sygnalizowane przez archidiakona krakowskiego Macieja Józefa Łubieńskiego (1742-1765) trudności we właściwym wypełnianiu obowiązków wynikających ze sprawowanej funkcji zadecydowały o powstaniu archidiakonatu wojnickiego. Pozytywnie ustosunkowała się do tej propozycji kapituła katedralna krakowska na posiedzeniu generalnym 11 sierpnia 1751 roku, a także trzy miesiące później (20 XI 1751 r.) archidiakon krakowski, wspomniany M.J. Łubieński. Stało się to podstawą do wydania przez biskupa krakowskiego A.S. Kostki Załuskiego, 1 grudnia 1751 roku, dekretu erygującego kolejny - siódmy - archidiakonat w diecezji krakowskiej z siedzibą w Wojniczu ${ }^{8}$. Początkowo jego terytorium obejmowały dwa dekanaty: lipnicki i wojnicki. Czternaście lat później (1765), na prośbę archidiakona wojnickiego Stanisława Cetnarskiego, biskup krakowski Kajetan Ignacy Sołtyk (1758-1788) włączył do archidiakonatu wojnickiego cztery dekanaty: Żmigród Nowy, Jasło, Biecz i Bobowa ${ }^{9}$. Łącznie obejmował on sześć dekanatów: Biecz, Bobowa, Jasło, Lipnica Murowana, Wojnicz, Żmigród Nowy.

${ }^{2}$ Tamże, kol. 871. Archidiakon wchodził w skład kapituły katedralnej i zajmował najczęściej miejsce trzecie (Gniezno, Płock, Wrocław, Lubusz) lub pierwsze (Kamień Pomorski).

${ }^{3}$ Tamże.

${ }^{4}$ B. Kumor, Dzieje diecezji krakowskiej do 1795 roku, t. 4, Kraków 2002, s. 23-24.

${ }^{5}$ Tamże, s. 25.

${ }^{6}$ T. Pawluk, Dekanat, EK, t. 3, red. F. Gryglewicz, Lublin 1989, kol. 1114. Pierwsze informacje o dekanatach na ziemiach polskich pochodzą z pierwszej połowy XIII wieku. Istniały już wówczas dekanaty: głogowski (1219), opolski (1223) i krośnieński (1226).

${ }^{7}$ B. Kumor, Dzieje diecezji krakowskiej do 1795 roku, t. 4, s. 71.

${ }^{8}$ Tamże, s. 71-72.

${ }^{9}$ Tamże, s. 72-73. 
Po 1772 roku zaszły duże zmiany w strukturze organizacyjnej Kościoła katolickiego na ziemiach polskich. Południowa część Rzeczypospolitej, tzw. Galicja, dostała się pod panowanie Austrii. Cesarz austriacki Józef II postanowił w 1782 roku, że granice diecezji i prowincji zakonnych muszą pokrywać się z granicami politycznymi zaboru. W tej sytuacji doszło do utworzenia w 1783 roku diecezji tarnowskiej dla galicyjskich części diecezji krakowskiej. Na pierwszego biskupa tarnowskiego został wyznaczony Jan Duwall. Papież Pius VI bullą z dnia 13 marca 1786 roku In suprema beati Petri cathedra potwierdził zaistniały stan rzeczy ${ }^{10}$. Przeprowadzona reorganizacja Kościoła w Galicji i utworzenie nowej diecezji tarnowskiej przyczyniły się do likwidacji w 1786 roku archidiakonatu wojnickiego.

$\mathrm{Na}$ terenie archidiakonatu wojnickiego w okresie jego istnienia znajdowały się dwie kolegiaty: w Wojniczu i Bobowej. Pierwsza z nich została ustanowiona przez biskupa krakowskiego Jana Lutka z Brzezia w 1465 roku przy kościele pw. św. Wawrzyńca w Wojniczu z trzema prałaturami (prepozytura, kustodia, scholasteria) oraz kolegium mansjonarzy. Kapituła kolegiacka w 1772 roku składała się z siedmiu prałatów (prepozyt, scholastyk, kustosz, dziekan, kantor, archidiakon i kanclerz) i sześciu kanoników. W takiej strukturze przetrwała do 1786 roku, kiedy to na wniosek biskupa tarnowskiego Floriana Amanda Janowskiego została skasowana przez cesarza Józefa $\mathrm{II}^{11}$. Druga kapituła - w Bobowej - została erygowana 9 października 1529 roku przez biskupa krakowskiego Piotra Tomickiego na prośbę właściciela Bobowej, Achacego Jordana z Zakliczyna. Biskup ustanowił w kapitule dwie prałatury (prepozyt, dziekan) i trzy kanonie gremialne, a także kolegium mansjonarzy ${ }^{12}$. W XVII wieku w kapitule utworzono jeszcze jedną prałaturę i kanonikat. W sumie pod koniec XVIII wieku kapituła liczyła trzech prałatów (prepozyt, dziekan, kustosz) i czterech kanoników ${ }^{13}$. Kapituła kolegiacka w Bobowej została zlikwidowana przez zaborcę austriackiego w 1791 roku, a jej uposażenie przeznaczono na Fundusz Religijny ${ }^{14}$.

Zgodnie z praktyką Kościoła (obecną zresztą do naszych czasów) kapituły kolegiackie erygowano przy znaczących świątyniach parafialnych. Istniejące często od wielu wieków kościoły, zanim podniesiono je do rangi kolegiat, posiadały księgozbiory, które służyły miejscowemu duchowieństwu w wykonywaniu obowiązków duszpasterskich. Księgozbiory te z chwilą podniesienia kościoła do rangi kolegiaty znacząco powiększały się, zazwyczaj w wyniku legatów testamentowych kanoników.

Biblioteka przy parafii, a następnie kolegiacie w Wojniczu, istniała zapewne od co najmniej XV wieku. Jednak pierwszy spis ksiąg pt. Inventarium librorum ecclesiae collegiatae woynicensis pochodzi dopiero z 1687 roku i obejmuje 66 po-

${ }^{10}$ B. Kumor, Diecezja tarnowska. Dzieje ustroju i organizacji 1786-1985, Kraków 1985, s. $38-52$.

${ }^{11}$ J.M. Marszalska, W. Graczyk, Zespoły proweniencyjne zasobu inkunabułów i starych druków Biblioteki Wyższego Seminarium Duchownego w Tarnowie. Właściciele, użytkownicy, bibliofile, Warszawa 2017, s. 166.

${ }^{12}$ Tamże, s. 177.

${ }^{13}$ Tamże, s. 178.

${ }^{14}$ Tamże, s. 180. 
zycji bibliograficznych ${ }^{15}$. Zaledwie cztery lata później (1691) ks. Jakub Spitmański sporządził drugi inwentarz ksiąg biblioteki kolegiaty wojnickiej. Ten z 1691 roku zawierał $70 \mathrm{ksiąg}^{16}$. Trzeci i ostatni inwentarz biblioteki kapitulnej (niestety niezachowany do chwili obecnej) został sporządzony w 1776 roku $^{17}$. Po likwidacji kapituły kolegiackiej (1786) księgi nadal pozostały przy kościele pw. św. Wawrzyńca w Wojniczu i przechowywano je najpierw w skarbcu kolegiaty, a od połowy XIX wieku w domu parafialnym. Trudno jednoznacznie stwierdzić, czy i na ile zasób biblioteki w XVIII wieku powiększył się. Prawie dwa wieki później, w latach 60. XX wieku, Józef Szymański dokonał zestawienia liczbowego ksiąg, które przez cały ten czas znajdowały się przy kościele w Wojniczu i wymienił jeden rękopis zawierający dzieła Arystotelesa Logika i Opera phisicorum - powstały prawdopodobnie w 1606 roku, 16 druków pochodzących z XVI, 24 z XVII i 29 druków z XVIII wieku ${ }^{18}$. Jeśli dołączy się do tego zestawienia 7 tytułów (w 12 woluminach) druków $\mathrm{XV}$-wiecznych, które zostały przewiezione do tarnowskiego seminarium duchownego ${ }^{19}$, to liczba dzieł wyniesie 77 .

Od strony zawartości treściowej był to bardzo interesujący zbiór tworzony w wyniku legatów najczęściej miejscowych kanoników, np. prepozyta kapituły Michała z Bystrzykowa, doktora teologii, profesora oraz rektora (1513-1514) Akademii Krakowskiej, autora wielu dzieł, np. Quaestiones in tractatus parvorum logicalium Petri Hispani (Kraków 1512), Quaestiones veteris ac novae logicae (Kraków 1507, wyd. 2 Kraków 1508, wyd. 3 Kraków 1511) ${ }^{20}$, prepozyta Jana Kwaśnickiego, studiującego latach 1594-1597 filozofię w Kolegium Jezuickim w Poznaniu, następnie w latach 1597-1602 teologię w Wilnie, od 1602 roku studenta Wydziału Filozofii Uniwersytetu Krakowskiego, który studia uwieńczył uzyskaniem stopni doktora filozofii i teologii ${ }^{21}$, czy altarysty wojnickiego Michała, profesora Akademii Krakowskiej i dziekana wydziału artium w 1546 roku $^{22}$. To właśnie Jan Kwaśnicki był kopistą zachowanego kodeksu rękopiśmiennego, zawierającego wykład logiki Arystotelesa (k. 1-366) oraz wykład fizyki Arystotelesa (k. 368-625). Choć nie odnotował w kodeksie swojego imienia i nazwiska, to umieszczony na kartach $34 \mathrm{v}$. oraz 35 zapis nie pozostawia wątpliwości co do osoby kopisty ${ }^{23}$.

${ }^{15}$ J. Szymański, Kapituła kolegiacka w Wojniczu 1465-1786, Lublin 1962, s. 221.

${ }^{16} 26$ listopada 1692 r. J. Spitmański został instytuowany prałatem kustoszem kapituły wojnickiej. Był ponadto proboszczem w Olszynach i Melsztynie oraz - w latach 1685-1893 - wikariuszem w Wojniczu. W 1694 roku zrezygnował z probostwa w Melsztynie. Zmarł w 1717 roku, został pochowany w kościele reformatów w Zakliczynie. Por. Szymański, Kapituła kolegiacka, s. 190-191.

${ }^{17}$ J. Szymański, Archiwum i biblioteka parafialna w Wojniczu, „Archiwa Biblioteki i Muzea Kościelne”, 2 (1961) z. 1-2, s. 175.

${ }^{18}$ Tamże.

${ }^{19}$ Marszalska, Graczyk, Zespoty proweniencyjne, s. 172.

${ }^{20}$ Tamże, s. 167.

${ }^{21}$ Por. Szymański, Kapituła kolegiacka, s. 172-173; Marszalska, Graczyk, Zespoły proweniencyjne, s. 168.

${ }^{22}$ Marszalska, Graczyk, Zespoły proweniencyjne, s. 168.

${ }^{23}$ L. Regner, Szesnastowieczny rękopis Biblioteki kapitulnej w Wojniczu, „Roczniki Filozoficzne", 10 (1962) nr 1, s. 173-187. 
O dużej wartości wojnickiego zbioru świadczy dobitnie liczba posiadanych druków XV-wiecznych (7 tytułów w 12 woluminach): Angelusa de Clavasio Summa angelica de casibus conscientiae [...] (Norymberga 1492) ${ }^{24}$, Biblia latina cum Postillis Nicolai de Lyra et expositionibus Guillelmi Britonis in omnes prologos S. Hieronymi et additionibus Pauli Burgensis replicisque Matthiae Doering. - Nicolaus de Lyra: Contra perfidiam Iudaeorum, pars I-IV, wydane w Norymberdze w $1487^{25}$, Bernardinusa de Bustis Rosarium sermonum cum additionibus illuminati Novariensis et Samuelis Cassinensis, pars I-II (Haguenau 1500) ${ }^{26}$, Gregoriusa I Magnusa Papae Homilia super Evangeliis w wydaniu augsburskim z 1473 roku $^{27}$, ponadto dzieło Petrusa Comestora Historia scholastica (Strasburg 1485) ${ }^{28}$, Pseudo-Petrusa de Palude Sermones thesauri novi de tempore (Strasburg 1489) ${ }^{29}$ oraz Antoninusa Florentinusa Chronicon, pars I-III (Bazylea 1491) ${ }^{30}$.

W zbiorze tym znajdują się księgi niezbędne do spełniania Służby Bożej, tj. Pismo św., jego liczne komentarze, a także dzieła kaznodziejskie ${ }^{31}$. Warte podkreślenia jest to, że w księgozbiorze nie zabrakło dzieł najpopularniejszego w średniowieczu glosatora, franciszkanina Mikołaja z Liry, a także Wilhelma Britoniusa, Pawła Burgendisa i św. Hieronima. Ich komentarze do tekstu Pisma św. znajdują się w wydaniu norymberskim Biblii z 3 grudnia 1487 roku Biblia cum postillis Nicolai de Lyra, t. 1-4, wydanej w znamienitej oficynie Antoniego Kobergera w Norymberdze $^{32}$. Fundamentalnym dziełem patrystyki łacińskiej jest Homilia super Evangellis Grzegorza I Wielkiego, wydana w Augsburgu w oficynie Güntera Zainera 28 sierpnia 1473 roku $^{33}$, a przechowywana obecnie w zbiorach biblioteki tarnowskiej. Ważnym dziełem z zakresu historiografii kościelnej, bardzo popularnym i to nie tylko w XV stuleciu była Historia scholastica Piotra Comestora, wydana w Strasburgu w 1485 roku $^{34}$, używana przez niemal całe średniowiecze jako podręcznik historii biblijnej ${ }^{35}$. Dzieło, zanim trafiło do zbiorów biblioteki seminaryjnej, przez pewien czas było własnością kaznodziei przy kościele pw.

${ }^{24}$ Biblioteka Wyższego Seminarium Duchownego w Tarnowie/Incunabuł (dalej: BWSDT/ Inc.), sygn. 4960. Zob. Katalog inkunabułów biblioteki Wyższego Seminarium Duchownego w Tarnowie, oprac. J.M. Marszalska, Tarnów 1997, s. 31.

${ }^{25}$ BWSDT/Inc., sygn. 5515; BWSDT/Inc., sygn. 5516; BWSDT/Inc., sygn. 5517; BWSDT/ Inc., sygn. 5518. Zob. Katalog inkunabułów, s. 41.

${ }^{26}$ BWSDT/Inc., sygn. 5521; BWSDT/Inc., sygn. 5522. Zob. Katalog inkunabułów, s. 45-46.

${ }^{27}$ BWSDT/Inc., sygn. 41270, adl.1. Zob. Katalog inkunabułów, s. 54.

${ }^{28}$ BWSDT/Inc., sygn. 5535, adl.1. Zob. Katalog inkunabutów, s. 73.

${ }^{29}$ BWSDT/Inc., sygn. 4653. Zob. Katalog inkunabułów, s. 74.

${ }^{30}$ Inkunabuł ten został zidentyfikowany przez prof. Jolantę M. Marszalską w 2011 roku podczas prowadzonych prac inwentaryzacyjnych. Nie została mu jeszcze nadana (2012) sygnatura przyporządkowująca do miejsca na półce.

${ }^{31}$ J.M. Marszalska, Piętnastowieczny księgozbiór Biblioteki Wyższego Seminarium Duchownego w Tarnowie, „Archiwa Biblioteki i Muzea Kościelne”, 80 (2003) s. 179-202.

${ }^{32}$ BWSDT/Inc., sygn. 5515, BWSDT/Inc., sygn. 5516, BWSDT/Inc., sygn. 5517, BWSDT/ Inc., sygn. 5518,

${ }^{33}$ BWSDT/Inc., sygn. 41270 adl. 1.

${ }^{34}$ BWSDT/Inc., sygn. 5535.

${ }^{35}$ Marszalska, Piętnastowieczny księgozbiór, s. 192. 
św. Floriana w Krakowie, Marcina z Brzeska: „Sum Martini de Brzesek [nieczyt.] anno 1524", następnie pomiędzy 1524 a 1526 rokiem ofiarowane przez niego Michałowi z Wojnicza, o czym świadczy zapis „Sum magistri Michaelis Voynitii per d. Martinum a Brzezek donatus concionatorem Crac. s. Floriani 1526". Przejawem tego, że księgi spełniały funkcję praktyczną, tzn. służyły pomocą w duszpasterstwie, w tym również do wygłaszania kazań, jest obecność w zbiorze dzieła dominikanina i profesora teologii w Paryżu Pseudo-Petrusa de Palude Sermones thesauri novi de tempore (Strasburg 1489) ${ }^{36}$. Z dziedziny historiografii kościelnej kolegiata posiadała w swoich zbiorach najbardziej popularne w XV stuleciu dzieło Piotra Comestora Historia scholastica, wydane w Strasburgu w 1485 roku $^{37}$ i używane przez niemal całe średniowiecze jako podręcznik historii biblijnej. Bardzo ważnym, zwłaszcza dla spowiedników, i poczytnym dziełem była summa spowiednicza Summa angelica de casibus conscientiae, wydana w Norymberdze w 1492 roku $^{38}$, autorstwa franciszkanina Angelusa de Clavasio (+1495).

O przynależności inkunabułów do biblioteki kolegiackiej w Wojniczu świadczą zachowane wpisy proweniencyjne: „Ecclesia Voynicensis” ${ }^{39}$, „Ex Bibliothecae Ecclesiae Collegiatae Voynicensis" ${ }^{40}$. Widoczne są różne wpisy osób prywatnych, w tym kanoników wojnickich. Na dziele Bernardyna de Bustis Rosarium sermonum [...] widnieją wpisy dwóch kanoników: Alberta Skoroszewskiego $^{41}$ „Ex libris Alberti Skoroszewski Praepositi Voynicensis”, z datą w tomie pierwszym - 1610 i w tomie drugim dzieła $-1615^{42}$, oraz Andrzeja Markowica ${ }^{43}$ „Sum fidelis possesor huius libri Andreas Markovic, plebanus in Jodłowka, prebendarius Voynicensis".

Zachowane XV-wieczne druki kolegiaty wojnickiej posiadają cenne, lecz zniszczone przez upływ czasu oprawy. W znakomitej większości stanowi je deska $\mathrm{z}$ naciągniętą brązową skórą, z widocznymi śladami wycisków geometrycznych i floraturowych oraz widocznymi fragmentami klamer i guzów środkowych i narożnych bądź śladami po nich. Jedynie Homilie do Ewangelii, autorstwa papieża Grzegorza Wielkiego, w latach 70 . XX wieku zostały poddane konserwacji zachowawczej ${ }^{44}$.

Jak już zaznaczono wyżej, 69 druków z kolegiaty wojnickiej pochodzi z wieków XVI-XVIII. Ich zawartość treściowa odzwierciedla klasyczny księgozbiór kościelny. W zbiorze tym obecna jest Biblia zawierająca zarówno Stary, jak i Nowy Testament: Biblia Sacra utriusque Testamenti iuxta veterem translationem

\footnotetext{
${ }^{36}$ BWSDT/Inc., sygn. 4653. Zob. Katalog inkunabułów, s. 74.

${ }^{37}$ BWSDT/Inc., sygn. 4653.

${ }^{38}$ BWSDT/Inc., sygn. 4960.

${ }^{39}$ BWSDT/Inc., sygn. 4960.

${ }^{40}$ BWSDT/Inc., sygn. 5515; BWSDT/Inc., sygn. 5516; BWSDT/Inc., sygn. 5517; BWSDT/

${ }^{41}$ Prepozyt wojnicki w latach 1609-1617. Por. Szymański, Kapituła kolegiacka, s. 190-191.

${ }^{42}$ BWSDT/Inc., sygn. 5521; BWSDT/Inc., sygn. 5522. Zob. Katalog inkunabułów, s. 45-46.

${ }^{43}$ Andrzej Markowic (1613-1617), kustosz wojnicki. Por. Szymański, Kapituła kolegiacka,

${ }^{44}$ Szerzej na ten temat por. Marszalska, Graczyk, Zespoly proweniencyjne, s. 166-176.
} Inc., sygn. 5518. s. 177. 
[...], Noremberge apud Fridericum Peypus Anno $1530^{45}$. O tym, że była związana ze środowiskiem kapitulnym wojnickim, świadczą zachowane proweniencje:

Biblia empta marca Anno 1532 per me [parochi ?] Voynycz; Anno Domini 1562 praesens liber per honorabilem Dominum Petrum Byczek substitutum sacerdotijs Voyniczensis [...] altariste testamentaliter et legaliter [...] exequitores 9 februari liber iste comparavit per loco Tarnoviensis donatus [...] Domino Stanislao Stasziczkij canonicus Voyniczenis Anno Domini 1581; F[rater] Nicolaus Roxolanus.

W zbiorze wojnickim XVI-XVIII wieku znajdują się również dzieła z zakresu kaznodziejstwa i ascetyki np.: Spiera Ambrosiusa Sermones quadragesimales [...] (Bazylea 1516) ${ }^{46}$; Jana Kantego Wuykowskiego Rekolekcye duchowne [...] (Kraków 1759) ${ }^{47}$. Wszystkie noszą widoczne (niedatowane) wpisy własnościowe biblioteki kolegiackiej: „Ex Bibliothecae Ecclesiae Collegiatae Voynicensis”. Dwa prywatne wpisy własnościowe widnieją na dziele Jana Wuykowskiego Rekolekcye duchowne [...] (Kraków 1759): „Ex libris Ioannis Josephi Adametz institutu vicarii Voynicensisi Anno Domini 1779” oraz „Ex libris Ioannis Adametz sumptibus Michael Tryba Anno 1779”. Wspomniany Jan Józef Adamecz należał w latach 1776-1816 do kolegium mansjonarzy przy kolegiacie wojnickiej ${ }^{48}$.

Biblioteka istniała również przy kolegiacie bobowskiej, po jej likwidacji zmieniła przynależność instytucjonalną z biblioteki kapitulnej na bibliotekę dekanalną, poniważ kościół i parafia w Bobowej była siedzibą dekanatu bobowskiego $^{49}$. Jedyny inwentarz ksiąg, jaki się zachował, został sporządzony prawie 100 lat po likwidacji kapituły w 1887 roku i nosił tytuł: Spis dziet znajdujacych sie $w$ bibliotece dekanalnej dekanatu bobowskiego. Został opracowany przez ówczesnego dziekana dekanatu bobowskiego, ks. Leona Kozłowskiego (1810-1891), o czym świadczy zapis: „Z urzędu dziekańskiego, Bobowa dnia 26 kwietnia 1887 roku. Ks. Leon Kołowski Dziekan”50. Do sporządzenia inwentarza ksiąg zobowiązał dziekana bobowskiego Konsystorz Biskupi w Tarnowie stosownym pismem przesłanym 30 marca 1887 roku. Dowiadujemy się o nim z odpowiedzi udzielonej przez ks. Leona Kozłowskiego dnia 27 kwietnia 1887 roku:

Najprzewielebniejszy Biskupi Konsystorzu, Odnośnie do nakazu z dnia 30 marca 1887 roku, przedkładam odpis katalogu biblioteki dekanalnej stosownie do oznaczonego terminu. $Z$ urzędu dziekańskiego, Bobowa dnia 27 kwietnia 1887. Ks. Leon Kozłowski, Dziekan ${ }^{51}$.

Łącznie w inwentarzu zostało odnotowanych 106 druków od XVI do XIX

${ }^{45}$ Biblioteka Wyższego Seminarium Duchownego w Tarnowie/Starodruk (dalej: BWSDT/SD), sygn. 68 .

${ }^{46} \mathrm{BWSDT} / \mathrm{SD}$, sygn. 31013.

${ }^{47}$ BWSDT/SD, sygn. 2759.

${ }^{48}$ BWSDT/SD, sygn. 2759. Kolegium mansjonarzy zostało erygowane w 1465 roku. Por. Szymański, Kapituła kolegiacka, s. 198, 200.

${ }^{49}$ Marszalska, Graczyk, Zespoty proweniencyjne, s. 180.

${ }^{50}$ Archiwum Diecezji Tarnowskiej (dalej: ADT), Spis dziet znajdujacych się w bibliotece dekanalnej dekanatu bobowskiego, sygn. AEp CT, A/75 (1887).

${ }^{51}$ Tamże. 
wieku. Na wiek XIX przypada 51 druków. To znaczy, że w bibliotece kapitulnej w chwili przemianowania jej po likwidacji kapituły na bibliotekę dekanalną mogło być kilkadziesiąt druków. Z XVI wieku pochodzi zaledwie jeden druk, z XVII - 6, z XVIII zaś 48 druków. Jeśli spośród druków XV-XVIII wieku zostanie wyłączonych kilka ksiąg, które trafiły do biblioteki dekanatu bobowskiego w XIX wieku jako legaty dwóch zasłużonych dziekanów bobowskich, tj. ks. Józefa Waxmundzkiego ${ }^{52}$ oraz ks. Wojciecha Skałbańskiego ${ }^{53}$, to liczba ksiąg w bibliotece kolegiackiej będzie mniejsza niż 55. Warto zaznaczyć, że o przynależności ksiąg do zbiorów wspomnianych wyżej duchownych świadczą zachowane zapisy proweniencyjne: „Ex Bibliotheca decanalis Boboviensis, post fata M.R. Josephi Waxmundzki derelictus". Ks. Waxmundzki umieszczał wpisy własnościowe następującej treści: „Ex Bibliotheca Josephi Waxmundzki mpp” na kartach przedtytułowych. Można odnaleźć je na dwóch XVII-wiecznych dziełach z zakresu kaznodziejstwa: Instructissima Bibliotheca manualis concionatoria [...] Tobiasza Lohnera w wydaniu weneckim z $1756^{54}$ oraz na dziele teologicznym Clausa Josepha Ignatiusa Spicilegium Universale sacro-profanum [...], wydanym w Wiedniu w $1762 \mathrm{roku}^{55}$. Nieco inny zapis proweniencyjny widnieje na karcie tytułowej dwutomowego dzieła Augusta Calmeta Prolegomena et Dissertationes in omnes et singulos S. Scripturae libros [...] (Wiedeń 1732), wskazuje on wprost na osobę dziekana bobowskiego Józefa Waxmundzkiego: „Spectunt ad Josephi Waxmundzki bibliotekarius”, nieco poniżej zaś innym charakterem pisma: „Ex libris bibliothecae decanalis Boboviensis, post fata M.R. Josephi Waxmundzki derelictus"56. Wpis innego dziekana bobowskiego, Wojciecha Skałbańskiego, widnieje na dziele Jana z Kartaginy Homilia catholica, wydanym w Kolonii w 1619 roku w oficynie Bernarda Gualthera: „Ex libris Adm. Reverendi Adalberti Skałbański [...] decani Boboviensis mpp" 57 .

Zapewne nakaz Konsystorza tarnowskiego o sporządzeniu inwentarza ksiąg był związany z planami przewiezienia zbiorów do Biblioteki Seminarium Duchownego w Tarnowie. Bardzo intensywny rozwój księgozbioru seminaryjnego odnotowuje się po 1888 roku, czyli od chwili objęcia rządów rektorskich przez ks. Józefa Bąbę ${ }^{58}$. W 1886 roku księgozbiór seminaryjny liczył 4004 woluminy, w 1904 roku zaś, kiedy ks. J. Bąba ustępował z urzędu po 16 latach sprawowania rządów rektorskich, zbiory biblioteczne liczyły już 5774 woluminy ${ }^{59}$.

Obecnie trudno jest odtworzyć zasób biblioteczny kapituły bobowskiej włą-

${ }^{52}$ Zob. A. Nowak, Józef Waxmundzki (Waksmundzki) (1764-1830), w: Stownik biograficzny kapłanów diecezji tarnowskiej, t. 4, Tarnów 2004, s. 180; Marszalska, Graczyk, Zespoły proweniencyjne, s. 180.

${ }^{53}$ Tamże, s. 181.

${ }^{54}$ BWSDT/SD, sygn. 6458; BWSDT/SD, sygn. 6459.

${ }^{55}$ BWSDT/SD, sygn. 5761.

${ }^{56}$ BWSDT/SD, sygn. 6459.

${ }^{57}$ BWSDT/SD. sygn. 34593; Marszalska, Graczyk, Zespoly proweniencyjne, s. 181.

${ }^{58}$ B. Kumor, Bąba Józef (1849-1936), EK, t. 2, red. F. Gryglewicz, Lublin 1976, kol. 154-155; Marszalska, Graczyk, Zespoły proweniencyjne, s. 26-28.

${ }^{59}$ Marszalska, Graczyk, Zespoly proweniencyjne, s. 28. 
czony do zbiorów biblioteki seminaryjnej, gdyż nie został wydzielony w formie odrębnej kolekcji, podobnie jak miało to miejsce w przypadku biblioteki wojnickiej $\mathrm{i}$ wielu innych. Jest to o tyle trudne, że obecnie księgozbiór seminaryjny w Tarnowie liczy 6249 tytułów w 5305 woluminach, tak rękopisów, jak i druków od XV do XVIII wieku ${ }^{60}$. A zatem możliwym sposobem, na podstawie którego można zrekonstruować księgozbiór bobowskich kanoników i ukazać jego znaczenie, pozostaje wspomniany inwentarz z 1887 roku oraz niektóre zidentyfikowane zapisy proweniencyjne pozostawione na kartach tytułowych ksiąg przez dawnych właścicieli i użytkowników kościoła kolegiackiego w Bobowej. Z analizy inwentarza ksiąg wynika, iż obok dzieł o tematyce teologicznej (moralna, dogmatyczna), pojedynczych traktatów filozoficznych czy ksiąg liturgicznych zdecydowanie przeważa tematyka kaznodziejska reprezentowana przez znanych autorów XVII i XVIII-wiecznych traktatów z tej dziedziny. Warto zaznaczyć, że najstarszym $\mathrm{z}$ druków wykazanych w inwentarzu jest Historia pontificium Romano, wydana w Kolonii w 1593 roku $^{61}$. A zatem kanonicy nie posiadali w swoim zbiorze starszych ksiąg bądź mogły one wcześniej ulec zniszczeniu. Jak zaznaczono, w bibliotekach kościelnych dział literatury kaznodziejskiej zajmował zawsze miejsce szczególne. Drukowano kazania, tzw. niedzielne i świąteczne, na różne okresy roku liturgicznego, pogrzebowe, panegiryczne, okolicznościowe czy na święta maryjne. Również w omawianym zbiorze można znaleźć dzieła z tego zakresu autorstwa kaznodziejów diecezjalnych, jak i zakonnych. Wśród wybitnych autorów swojej epoki można odnaleźć w spisie dzieło Szymona Starowolskiego (1588-1656), kanonika krakowskiego, polihistora i kaznodziei ${ }^{62} \mathrm{pt}$. Świątnica Pańska, kazania całego roku, wydane w Krakowie w 1682 roku $^{63}$. Z kręgu zakonnego dużą popularnością w XVIII wieku cieszył się jezuicki kaznodzieja Kasper Balsam, z którego kazań chętnie korzystano ${ }^{64}$. W bibliotece kolegiackiej przechowywano dwa tomy jego kazań: Kazania na niedziele całego roku na dwa tomy podzielone, t. 1 (Poznań 1761), Kazania na święta całego roku, t. 2 (Poznań 1764) ${ }^{65}$, a także dzieło wybitnego jezuickiego pedagoga, Sebastiana Ubermanowicza (1698-1764) ${ }^{66}$, popularyzatora teologii, którego Religia, cnota i doskonatość chrześcijańska po kaznodziejsku wyłożona..., (Kalisz 1760) było również na półkach biblioteki kolegiaty bobowskiej. Po wspomniane dzieło

60 Tamże, s. 32-33.

${ }^{61}$ ADT, Spis dziet znajdujących się w bibliotece dekanalnej dekanatu bobowskiego, sygn. AEp CT, A/75 (1887).

${ }^{62}$ E. Ozorowski, Starowolski Szymon (1588-1656), w: Słownik Polskich Teologów Katolickich (dalej: SPTK), t. 4, red. H.E. Wyczawski, Warszawa 1983, s. 187-193.

${ }^{63}$ ADT, Spis dziel znajdujących się $w$ bibliotece dekanalnej dekanatu bobowskiego, sygn. AEp CT, A/75 (1887).

${ }^{64}$ L. Grzebień, Balsam Kasper (1715-1759), SPTK, t. 1, red. H.E. Wyczawski, Warszawa 1981, s. 93-94; J. Bazydło, Balsam Kasper (1715-1759), EK, t. 1, Lublin 1989, kol. 1288.

${ }^{65}$ ADT, Spis dzieł znajdujacych się w bibliotece dekanalnej dekanatu bobowskiego, sygn. AEp CT, A/75 (1887).

${ }^{66}$ L. Grzebień, Ubermanowicz Sebastian (1698-1764), SPTK, t. 4, red. H.E. Wyczawski, Warszawa 1983, s. 365-366. 
S. Ubermanowicza chętnie sięgano, gdyż jego autor był nie tylko wybitnym pedagogiem, ale również znakomitym kaznodzieją, czego wyraz dawał na dworze króla Stanisława Leszczyńskiego w Luneville ${ }^{67}$. Z jego cennych wskazówek kaznodziejskich chętnie korzystano w kolegiacie bobowskiej. Z kolei ze środowiska paulińskiego wywodził inny z kaznodziejów Teodor Jan Gruber (1740-1808), który zasłynął jako wymowny homiletyk, wydał cykle kazań adwentowych, postnych, maryjnych i świątecznych, bardzo popularnych w XVIII wieku ${ }^{68}$, które służyły jako klasyczne pomoce duszpasterskie. W księgozbiorze bobowskim znajdował się jeden z tomów dzieła T. Grubera, pt. Kazania niedzielne księdza Teodora Grubera zakonu s. Pawta pierwszego Pustelnika, t. 2-3 (Częstochowa 1778) ${ }^{69}$, jak również Myśli przebrane, wydane w Częstochowie w 1778 roku $^{70}$.

Z kręgu franciszkańskiego (reformackiego) odnotowano dzieło reformaty Feliksa Synakiewicza (zm. po 1792 r.), który pełnił przez pewien czas obowiązki kaznodziei w katedrze włocławskiej. Głoszone przez niego kazania zostały wydane w trzytomowym zbiorze zatytułowanym Kazania na niedziele całego roku w katedrze wtoctawskiej miane w 1779 roku, w Warszawie w latach 1785-1790 ${ }^{71}$. W bibliotece kapitulnej w Bobowie znajdował się tylko tom pierwszy tego dzieła, wydany w Warszawie w 1785 roku $^{72}$. Z kolei środowisko kaznodziejskie bernardynów reprezentował wybitny teolog-moralista i zarazem kaznodzieja bernardyński Gaudenty Pikulski (zm. 1763) ${ }^{73}$ swoim dziełem Panis quotidianus juventutis sacrae in laborioso examine ad ordines..., wydanym we Lwowie w 1750 roku. Dzieło to obejmujące zagadnienia teologii moralnej, liturgiki oraz prawa kanonicznego przeznaczone było dla duchownych pracujących $\mathrm{w}$ duszpasterstwie i cieszyło się dużym zainteresowaniem wśród duchowieństwa parafialnego. Zdaniem Hugo Kołłątaja dzieło G. Pikulskiego wraz z Medulla theologiae moralis Henryka Busenbauma można było najczęściej spotkać w bibliotekach parafialnych $^{74}$. Z kolei praktyczny wymiar piśmiennictwa związany przede wszystkim z sakramentem pokuty i duszpasterstwem odzwierciedla dzieło Theologia moralis universa, autorstwa francuskiego jezuity Pawła Gabriela Antoine, wydane w Krakowie w 1741 roku, obecne również w bibliotece kapitulnej ${ }^{75}$. Służyło pomocą spowiednikom w kościele kolegiackim w Bobowej.

${ }^{67}$ Tamże, s. 366.

${ }^{68}$ P. Gach, Gruber Jan Teodor (1740-1808), EK, t. 6, red. J. Walkusz, Lublin 1993, kol. 208.

${ }^{69} \mathrm{ADT}$, Spis dziel znajdujących się w bibliotece dekanalnej dekanatu bobowskiego, sygn. AEp CT, A/75 (1887). Sporządzający inwentarz nie odnotował, który z tomów przechowywany był w bibliotece kapitulnej w Bobowej.

${ }^{70}$ Tamże.

${ }^{71}$ A.J. Steinke, Synakiewicz Feliks (zm. po 1792), SPTK, t. 4, red. H.E. Wyczawski, Warszawa 1983, s. 240-242.

${ }^{72}$ ADT, Spis dzieł znajdujących się w bibliotece dekanalnej dekanatu bobowskiego, sygn. AEp CT, A/75 (1887).

${ }^{73}$ H.E. Wyczawski, Pikulski Gaudenty (zm. 1763), SPTK, t. 3, red. H.E. Wyczawski, Warszawa 1982, s. 359-360.

${ }^{74}$ H. Kołłataj, Pamiętnik o stanie duchowieństwa katolickiego polskiego innych wyznań w potowie XVIII wieku, wyd. J.K. Żupański, Poznań 1840, s. 38.

${ }^{75}$ ADT, Spis dzieł znajdujących się w bibliotece dekanalnej dekanatu bobowskiego, sygn. AEp CT, A/75 (1887). 
Oprócz dzieł z zakresu kaznodziejstwa, księgozbiory kościelne gromadziły również Pismo św. i jego komentarze. Wynikało to z potrzeby głębszego zrozumienia i przyswojenia sobie treści w nim zawartych. Znanym i rozpowszechnionym XVII-wiecznym komentatorem Biblii, którego dzieło jest obecne w księgozbiorze kapitulnym, był biblista benedyktyński Calmet Antoine (zakonne Augustyn). Jest on autorem Prolegomena et disertationes, wydanej w Augustae Vindelicorum (Augsburg) w 1734 roku $^{76}$.

Do nauczania teologii dogmatycznej w XVIII wieku najczęściej używane były dzieła francuskiego lazarysty i wybitnego teologa, Piotra Colleta (1693-1770), zdecydowanego przeciwnika jansenizmu, który z czasem uległ umiarkowanemu gallikanizmowi. Warto zaznaczyć, że powszechnie w nauczaniu teologii w seminariach pod koniec XVIII i w XIX stuleciu używano jego podręcznika Institutiones theologicae ad usum seminariorum, który był kontynuacją XVI-tomowej dogmatyki i sakramentologii Honorata Tournelyego, wydanej w latach 1725-173077. Egzemplarz tego dzieła przechowywany w bibliotece kapituły bobowskiej został wydany w Chełmnie n. Wisłą w 1765 roku. Biblioteka posiadała wszystkie cztery tomy tego wydawnictwa ${ }^{78}$. Biblioteki kościelne dysponowały często podstawowymi dziełami z zakresu filozofii. Bardzo popularnym w środowisku katolickim był Arystoteles. Podejmował rozważania metasystemowe oraz stworzył teorię metafizyczną, etyczną i filozofię przyrody. Obok Platona był najwybitniejszym myślicielem starożytności. Nic więc dziwnego, że jego myśl doczekała się licznych komentarzy i omówień. W księgozbiorze kapituły bobowskiej znajdowało się interesujące dzieło o tematyce filozoficznej jezuity Adama Kwiryna Krasnodębskiego (1628-1702), profesora kursu filozofii w latach 1674-1677 w kolegium jezuickim w Pułtusku ${ }^{79}$, zatytułowane Philosophia Aristotelis explicata, wydane w Warszawie w 1678 roku $^{80}$.

Podsumowując, należy podkreślić, że istniejące w granicach archidiakonatu wojnickiego dwie kolegiaty posiadały swoje księgozbiory. Od strony zasobności były to biblioteki zbliżone, kolegiata w Wojniczu - 77 tytułów, w Bobowej - ok. 50. O ich znaczeniu i wartości decyduje przede wszystkim obecność w zbiorze książki XV-wiecznej, tzw. inkunabułów. W bibliotece wojnickiej znajdowało się ich 7 tytułów w 12 woluminach.

W bibliotece bobowskiej XIX-wieczny inwentarz nie wykazał obecności żadnego druku z XV wieku. Najstarsza księga, jaką odnotowano w inwentarzu kolegiaty bobowskiej to druk z 1593 roku, a zatem już dość późny. Bobowa, znacznie oddalona od większych ośrodków miejskich swojej epoki (od Krakowa dzieliło ją ok. $120 \mathrm{~km}$, od Wojnicza zaś ok. $40 \mathrm{~km}$ ), miała już nieco inne oddziaływanie.

76 Tamże.

${ }^{77}$ W. Graczyk, Księgozbiór klasztoru-eremu karmelitów bosych w Czernej od końca XVII do końca XIX wieku. Studium z dziejów kultury intelektualnej i duchowej, Kraków 2011, s. 142.

${ }^{78} \mathrm{BKC}$, sygn. 1279, poz. inw. 1356; BKC, sygn. 1280, poz. inw. 1357; BKC, sygn. 1281, poz. inw. 1358; BKC, sygn. 1282, poz. inw. 1359; BKC, sygn. 1283, poz. inw. 1360; BKC, sygn. 1284, poz. inw. 1361 .

${ }^{79}$ L. Grzebień, Krasnodębski Adam Kwiryn h. Pobóg (1628-1702), SPTK, t. 2, red. H.E. Wyczawski, Warszawa 1982, s. 414-415.

${ }^{80}$ ADT, Spis dziet znajdujacych się w bibliotece dekanalnej dekanatu bobowskiego, sygn. AEp CT, A/75 (1887). 
Z kolei obecność inkunabułów i ważnych od strony zawartości treściowej druków z XVI-XVIII wieku w bibliotece wojnickiej była następstwem bliskich związków ośrodka kościelnego wojnickiego z uniwersytetem w Krakowie, zwłaszcza w XVI wieku. Widać to choćby na przykładzie prepozyta kapituły Michała z Bystrzykowa, doktora teologii, profesora oraz rektora Akademii Krakowskiej, jednego z najwybitniejszych teologów w ówczesnej Polsce, prepozyta Jana Kwaśnickiego, absolwenta filozofii Kolegium Jezuickiego w Poznani, wydziału teologii w Wilnie, a od 1602 roku studenta Wydziału Filozofii Uniwersytetu Krakowskiego, czy altarysty wojnickiego Michała, profesora Akademii Krakowskiej i dziekana wydziału artium w 1546 roku. Kontakty kanoników wojnickich $\mathrm{z}$ ośrodkiem uniwersyteckim krakowskim i środowiskiem naukowym kształtowały ich horyzonty intelektualne, czego następstwem było świadome gromadzenie wczesnych ksiąg drukowanych (XV w.). Co ważne, księgi te były użytkowane, o czym świadczą zachowane podkreślenia tekstu czy marginalia wielu rąk. $\mathrm{Na}$ zachowanych księgach kolegiaty bobowskiej śladów ich użytkowania w dawnych wiekach jest znacznie mniej. W XVIII stuleciu szczególną dbałość o księgi wykazywali kolejni dziekani bobowscy: ks. Józef Waxmundzki i ks. Wojciech Skałbański, którzy „zaznaczyli swoją obecność" na księgach poprzez uczynione zapisy proweniencyjne.

A zatem trzon obydwu zasobów bibliotecznych stanowiły księgi z zakresu teologii, kaznodziejstwa, filozofii, prawa i historii. Znajdowały się w nich wydania dzieł ojców Kościoła, Biblii czy wydania dzieł uznanych teologów, co jest szczególnie widoczne w księgozbiorze wojnickim. Rangę zbioru wojnickiego podnoszą zachowane do dziś cenne oprawy gotyckie i renesansowe wielu XV-wiecznych ksiąg, nieco zniszczone przez upływ czasu. W obu zbiorach wiele miejsca zajmował dział kaznodziejstwa polskiego i europejskiego, na który składały się traktaty z zakresu wymowy kościelnej i teorii homiletyki oraz bardzo liczne kazania (tzw. niedzielne i świąteczne na różne okresy roku liturgicznego, kazania pogrzebowe, panegiryczne i okolicznościowe). W księgozbiorze wojnickim były to jeszcze średniowieczne sermones znakomitych autorów (Pseudo-Petrusa de Palude), w księgozbiorze kolegiaty bobowskiej zaś kaznodziejstwo XVII i XVIII-wieczne, z przewagą XVIII stulecia. Obie biblioteki kolegiackie, choć powstały w różnym czasie (Wojnicz 1465, Bobowa 1529), gromadziły księgi tematycznie związane z pracą duszpasterską. Powiększały się zasadniczo na skutek legatów testamentowych i darowizn. Szczególnie widoczne jest to na przykładzie biblioteki kolegiaty wojnickiej. Bez wątpienia księgozbiór kolegiaty w Wojniczu należał do znaczących pod względem zawartości treściowej ksiąg, jak również czasu ich wydania, w Bobowej zaś miał zdecydowanie charakter pragmatyczny. 


\section{BIBLIOGRAFIA}

\section{Źródła}

Archiwum Diecezji Tarnowskiej (ADT)

sygn. AEp CT, A/75 (1887),

Spis dziet znajdujacych się $w$ bibliotece dekanalnej dekanatu bobowskiego.

\section{Opracowania}

Gach Piotr Paweł, Gruber Jan Teodor (1740-1808), w: Encyklopedia katolicka, t. 6, red. J. Walkusz, Lublin 1993, kol. 208.

Graczyk Waldemar, Księgozbiór klasztoru-eremu karmelitów bosych w Czernej od końca XVII do końca XIX wieku. Studium z dziejów kultury intelektualnej i duchowej, Kraków 2011.

Grzebień Ludwik, Krasnodębski Adam Kwiryn h. Pobóg (1628-1702), w: Słownik Polskich Teologów Katolickich, t. 2, red. H.E. Wyczawski, Warszawa 1982, s. 414-415.

Kołłataj Hugo, Pamiętnik o stanie duchowieństwa katolickiego polskiego innych wyznań w połowie XVIII wieku, wyd. J.K. Żupański, Poznań 1840.

Kumor Bolesław, Archidiakonat, w: Encyklopedia katolicka, t. 1, red. F. Gryglewicz, Lublin 1973, kol. 869.

Kumor Bolesław, Bąba Józef (1849-1936), w: Encyklopedia katolicka, t. 2, red. F. Gryglewicz, Lublin 1976, kol. 154-155

Kumor Bolesław, Diecezja tarnowska. Dzieje ustroju i organizacji 1786-1985, Kraków 1985.

Kumor Bolesław, Dzieje diecezji krakowskiej do 1795 roku, t. 4, Kraków 2002.

Marszalska Jolanta Małgorzata, Katalog inkunabułów biblioteki Wyższego Seminarium Duchownego w Tarnowie, Tarnów 1997.

Marszalska Jolanta Małgorzata, Piętnastowieczny księgozbiór Biblioteki Wyższego Seminarium Duchownego w Tarnowie, „Archiwa Biblioteki i Muzea Kościelne”, 80 (2003) s. $179-202$.

Marszalska Jolanta Małgorzata, Graczyk Waldemar, Zespoły proweniencyjne zasobu inkunabułów i starych druków Biblioteki Wyższego Seminarium Duchownego w Tarnowie. Właściciele, użytkownicy, bibliofile, Warszawa 2017.

Ozorowski Edward, Starowolski Szymon (1588-1656), w: Stownik Polskich Teologów Katolickich, t. 4, red. H.E. Wyczawski, Warszawa 1983, s. 187-193.

Pawluk Tadeusz, Dekanat, w: Encyklopedia katolicka, t. 3, red. F. Gryglewicz, Lublin 1989, kol. 1114.

Regner Leopold, Szesnastowieczny rękopis Biblioteki kapitulnej w Wojniczu, „Roczniki Filozoficzne", 10 (1962) nr 1, s. 173-187.

Steinke Anzelm Janusz, Synakiewicz Feliks (zm. po 1792), w: Słownik Polskich Teologów Katolickich, t. 4, red. H.E. Wyczawski, Warszawa 1983, s. 240-242.

Szymański Józef, Archiwum i biblioteka parafialna $w$ Wojniczu, „Archiwa Biblioteki i Muzea Kościelne", 2 (1961) z. 1-2, s. 167-176.

Szymański Józef, Kapituła kolegiacka w Wojniczu 1465-1786, Lublin 1962.

Wyczawski Hieronim Eugeniusz, Pikulski Gaudenty (zm. 1763), w: Stownik Polskich Teologów Katolickich, t. 3, red. H.E. Wyczawski, Warszawa 1982, s. 359-360. 
THE BOOK COLLECTIONS BELONGING TO THE COLLEGES OF CANONS IN THE ARCHDEACONRY OF WOJNICZ UNTIL 1786

\section{Summary}

The two collegiate churches existing in the archdeaconry of Wojnicz, in Wojnicz and Bobowa, possessed their own libraries with a similar number of books: the collegiate church in Wojnicz had 77 titles and the one in Bobowa around 50 titles. The core collections of both libraries comprised books on theology, preaching, philosophy, law and history. The Wojnicz collection acquired a special significance thanks to numerous fifteenth-century books in the surviving Gothic and Renaissance bindings which are of great value and only slightly damaged by the passage of time. Although these two libraries were established at different times (Wojnicz in 1465 and Bobowa in 1529) and circumstances, they both collected books related to pastoral work, particularly visible in the case of Bobowa. In the case of the collegiate church in Wojnicz, a number of valuable books were in the possession of canons, who collected them for their studies and work at the university, and then bequeathed them to the libraries of the collegiate churches. Undoubtedly, the library in Wojnicz ranked among the most significant book collections in terms of its content and the time of publication, while the one in Bobowa definitely served pragmatic purposes.

Key words: Wojnicz; Bobowa; book collection; collegiate church; canons 